\title{
Pesquisa em Biologia Molecular: Como Fazer?
}

\author{
Molecular Biology Research - How to do it?
}

\author{
MAURODE SOUZA LEITEPINHO-TSBCP
}

PINHO MSL. Pesquisa em Biologia Molecular: como fazer? Rev bras Coloproct, 2006;26(3): 331-336.

\begin{abstract}
RESUMO: O estudo da biologia molecular representa hoje uma das áreas de maior potencial para a realização de pesquisas em Medicina e um número cada vez maior de profissionais de saúde tem se interessado em aprofundar seus conhecimentos e produção científica, mediante a realização de projetos de pesquisa nesta área. Entretanto, a elaboração do projeto de pesquisa necessita ser realizada de forma bastante cuidadosa, considerando a grande amplitude dos potenciais objetivos e metodologias a serem utilizadas, dependentes em grande parte da disponibilidade de recursos tecnológicos e experiência prévia da equipe. $O$ objetivo deste trabalho é contribuir para esta elaboração do projeto de pesquisa através da apresentação de alguns modelos estruturais mais freqüentemente utilizados na realização de estudos em biologia molecular, assim como rever seus princípios e métodos empregados.
\end{abstract}

Descritores: Pesquisa, biologia molecular.

O estudo da biologia molecular representa hoje uma das áreas de maior potencial para a realização de pesquisas na área médica, considerando-se não apenas sua grande relevância clínica e epidemiológica, mas também pela possibilidade de aplicação de ferramentas recentemente desenvolvidas a um número bastante amplo de doenças.

Em conseqüência do grande interesse despertado por esta área, observa-se um número cada vez maior de profissionais da área de saúde motivados em aprofundar seus conhecimentos e produção científica, mediante a realização de projetos de pesquisa, os quais de alguma forma utilizem conceitos e procedimentos relacionados á biologia molecular.

Entretanto, já aos primeiros passos neste caminho o candidato a pesquisador defronta-se com questões bastante complexas referentes não apenas à escolha do tema a ser estudado, mas principalmente á definição de seus objetivos gerais, específicos ou mesmo aos recursos adequados e/ou disponíveis para a execução de sua metodologia.

Assim sendo, o objetivo deste texto será apresentar uma breve revisão de conceitos básicos sobre a biologia molecular, confrontando-os com a respectiva seqüência de potenciais áreas e metodologias de pesquisa.

\section{BIOLOGIA MOLECULAR: O QUE É ?}

Até algumas décadas atrás, o estudo dos tecidos vivos baseava-se quase que exclusivamente em observações de natureza morfológica, fossem estas a nível macroscópico ou microscópico. Desta forma, a análise das alterações ocorridas na intimidade destes tecidos poderiam ser identificadas apenas mediante a constatação de seus efeitos sobre sua estrutura, a qual iria apresentar modificações em sua forma, tamanho, aparência e outras variáveis.

O grande e acelerado desenvolvimento da tecnologia permitiu que estes mesmos tecidos fossem posteriormente analisados em seu conteúdo submicroscópico, ou seja, através da identificação das moléculas que os compõem pela aplicação de métodos químicos ou físicos.

O grande salto de conhecimento ocorrido nesta área foi proporcionado pelos trabalhos pioneiros de Watson e Crick, na década de 50, os quais, ao definir a estrutura química da molécula de DNA, estabelece-

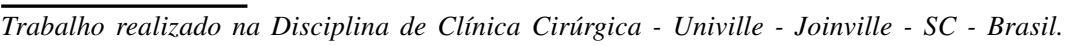

$\overline{\text { Recebido em 01/06/2006 }}$

Aceito para publicação em 08/08/2006 
ram a principal diferença entre os seres vivos e a matéria inanimada.

A partir deste achado, sucedeu-se uma sequiência de descobertas que demonstrou que esta molécula representava o elemento primordial, a partir do qual poderíamos compreender as principais características dos seres vivos. Nascia a biologia molecular.

\section{VIDA, DNA, GENES, PROTEÍNAS}

A identificação da molécula de DNA possibilitou uma melhor compreensão do ciclo finito da vida, descrito como o intervalo entre os processos de nascimento e morte, e mantido através de um constante funcionamento baseado na ação de moléculas, a qual seria o elemento básico das transformações morfológicas observadas de forma peculiar em cada ser vivo no reino animal ou vegetal.

Para melhor analisarmos o impacto destas descobertas, consideremos como elemento vivo uma única célula, mínimo organismo capaz de realizar as tarefas inerentes á vida como captação de energia e o metabolismo interno necessário durante o seu ciclo de existência.

Os estudos bioquímicos nos trouxeram o conhecimento de que as principais moléculas responsáveis pela realização destas tarefas são as proteínas. Estas macromoléculas, compostas por seqüências de aminoácidos, representam a maior parte de matéria seca de uma célula. Além de auxiliar a compor sua estrutura, as proteínas realizam praticamente todas as funções celulares, como enzimas, transporte, transmissão de sinais, recepção de estímulos e até a regulação da ativação de genes para a produção de outras proteínas.

Estima-se hoje que cada célula necessite para seu funcionamento vital de cerca de 10000 proteínas diferentes, cada uma delas desempenhando uma tarefa específica.

Estas proteínas, como sabemos, são produzidas a partir de segmentos de seqüências gênicas no DNA, através da qual se estruturam moléculas de RNA, descritas como mensageiras (RNAm). Estas moléculas irão migrar a partir do DNA nuclear para os ribossomos, no citoplasma, onde, através de ligações com outra forma de RNA (descrito como transportador), irão realizar a síntese das proteínas mediante o encadeamento seqüencial de aminoácidos. Poderíamos então sumarizar esta seqüência de eventos da seguinte forma:

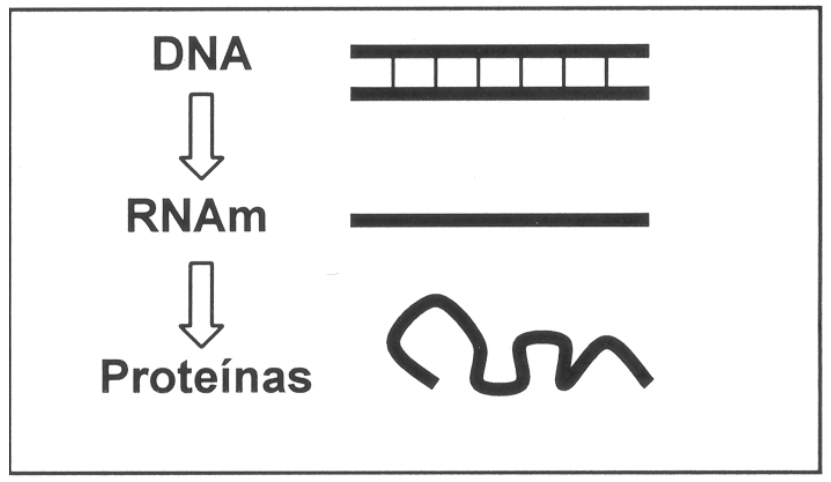

\section{Estruturando um projeto de pesquisa em biologia molecular}

Utilizando os conceitos acima revistos, discutiremos a seguir três tipos de projetos mais freqüientemente utilizados em biologia molecular:

$1^{\circ}$ tipo: Pesquisar no DNA de um indivíduo saudável o risco de desenvolver uma doença de caráter hereditário

Esta é certamente um dos tipos de projetos de pesquisa mais realizados, representando a base do estudo das doenças genéticas. Como exemplo clássico na área da Coloproctologia para este modelo de estudo, podemos citar a necessidade de identificar se um membro de uma família de um paciente portador de polipose adenomatosa familiar terá ou não o risco de desenvolver a mesma doença. Neste caso, sabemos que o gene responsável pela ocorrência desta doença é dominado como APC, cuja função é codificar uma proteína relacionada ao controle da atividade proliferativa da célula intestinal.

Para realizar este estudo, precisamos responder às seguintes perguntas:

- A seqüência deste gene APC em um DNA normal (sem mutações) já é conhecida?

Sim, como a maior parte dos genes de relevância clínica, sua seqüência já é publicamente disponível em bases de dados facilmente acessíveis pela Internet;

Já foi identificada a mutação existente no paciente portador da polipose?

Provavelmente não. Neste caso, teremos necessariamente que fazer um sequenciamento de todo o gene APC deste paciente, em qualquer célula normal somática (ou seja, excluindo óvulos e espermatozóides), pois ao se tratar de uma mutação (também chamada 
de polimorfismo) provavelmente herdada geneticamente, esta deve estar necessariamente universalmente presente. Para esta finalidade, utiliza-se mais freqüentemente as células sanguíneas, cujo DNA é extraído.

Para realizar esta avaliação da sequiência de todo o gene, necessitaremos utilizar seqüenciadores eletrônicos, os quais nos permitirão determinar a seqüência de bases nitrogenadas (adenina, citosina, guanina e timina) no segmento desejado, conforme demonstrado na figura 1, e compará-la com a seqüência previamente conhecida.

Este é um procedimento ainda disponível em poucos centros, demorado e de alto custo, especialmente se considerarmos que o gene APC é bastante longo, contendo 8535 pares de bases nitrogenadas. Caso este exame seja possível, e tenha sido possível identificar uma mutação em algum segmento (como uma troca de uma adenina por timina, por exemplo), então estaremos aptos a prosseguir em nosso estudo.

- Como saber se um familiar assintomático apresenta a mesma mutação em seu DNA?

Para isto, bastar extrair o DNA de algum tecido celular deste paciente (sangue, esfregaço da bochecha, etc) para pesquisar se esta mutação estará presente. Como neste caso já sabemos onde e qual a mutação a ser procurada, não necessitamos fazer um sequenciamento novamente. Para isto, podemos apenas utilizar uma técnica de amplificação do DNA denominada como reação em cadeia pela polimerase (PCR), a qual irá permitir a replicação in vitro em lar-

\section{5}
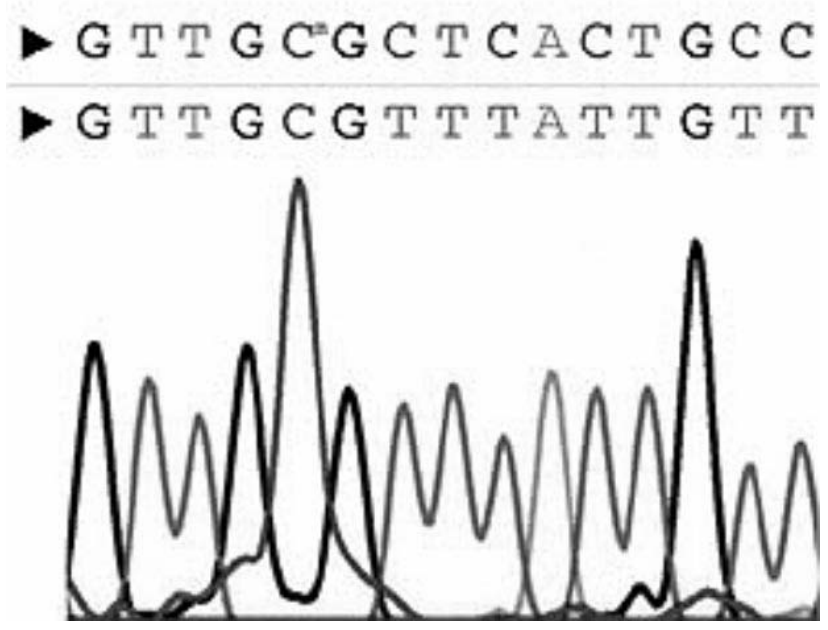

Figura 1 - Sequenciamento do DNA. ga escala apenas do segmento de DNA desejado, ou seja, aquele no qual está contida a seqüência que apresentou a mutação no familiar doente.

Caso o laboratório disponha de aparelhos de PCR mais modernos (real-time PCR) esta identificação e mensuração dos segmentos a serem examinados poderá ser realizada eletronicamente, no chamado tempo real. Caso o aparelho de PCR não disponha deste recurso, o produto de sua amplificação deverá ser identificado posteriormente em gel de eletroforese (Figura 2). Como qualquer alteração na sequiência de DNA implicará uma alteração de seu peso molecular, será possível observar se a sequiência do segmento gênico examinado está íntegra ou não, pois o peso molecular do segmento normal é conhecido (Figura 3).

Este tipo de estudo é, portanto, utilizado quando desejamos conhecer a existência de uma alteração genética, hereditária ou não, e é usualmente descrito como pesquisa de polimorfismos.

$2^{\circ}$ tipo: Pesquisa de DNA estranho ao indivíduo em um tecido

Este tipo de estudo, de grande relevância na esfera da infectologia, é semelhante a este último apresentado acima, com a diferença de que o segmento de DNA pesquisado no tecido do indivíduo não é uma variação de uma seqüência gênica humana normal, mas uma sequiência presente exclusivamente em um determinado ser vivo de outra espécie, seja este um vírus ou bactéria, denotando assim a sua presença anômala.

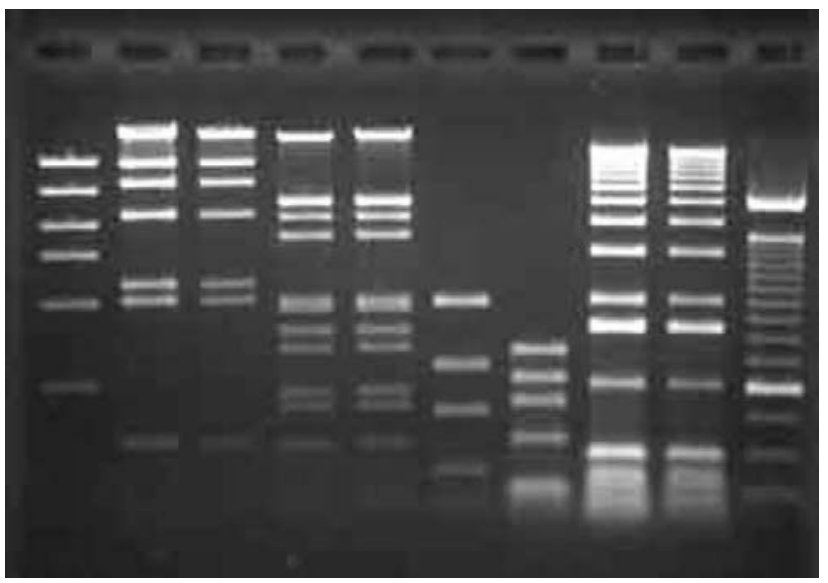

Figura 2 - Gel de agarose contendo dez amostras teciduais, nas quais fragmentos de DNA podem ser identificados através de seu posicionamento decorrente de seu peso molecular. 


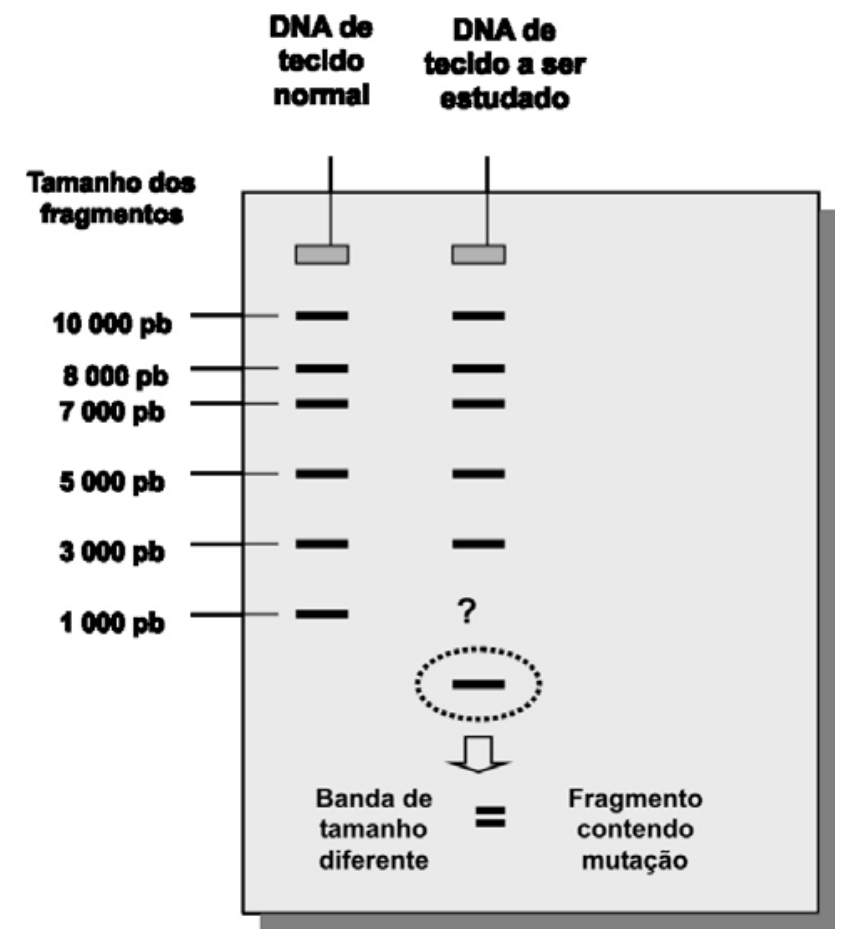

Figura 3 - Eletroforese em gel de fragmentos de DNA. Observe que a alteração na banda mais inferior do DNA do tecido a ser estudado revela uma provável mutação em relação ao fragmento normal correspondente ao peso molecular de 1000 pb (pares de bases).

Como exemplo, vamos definir como nossa hipótese que a ileite em um paciente portador de diarréia é causada pela presença de uma infecção por Yersinia enterocolitica. Neste caso, como poderemos utilizar as ferramentas da biologia molecular para fazer este diagnóstico?

- Extração do DNA a partir de uma biópsia do íleo terminal colhida por colonoscopia

Trata-se de um procedimento bioquímico relativamente simples, podendo ser realizado por laboratórios bem equipados com pessoal treinado.

\section{PCR}

- Pesquisa do DNA da Yersinia através de

Neste caso, a técnica de reação em cadeia pela polimerase deverá incluir, além do DNA ileal extraído, pequenas sequiências (denominadas como primers) previamente preparadas para amplificar apenas um segmento conhecido do DNA da Yersinia.

Se neste tecido houver DNA da Yersinia, mesmo em mínima quantidade, este será amplificado e identificado pelo PCR (em tempo real ou no gel de eletroforese), gerando um resultado preciso e sem ne- cessidade de realização da cultura, nem sempre disponível.

Embora tenhamos utilizado um exemplo referente a tecido intestinal, exames análogos de identificação de DNA extrínseco podem também ser realizados em outros tecidos, incluindo o sangue circulante, o que é feito com grande freqüência, por exemplo, no diagnóstico de infecções virais sistêmicas.

$3^{\circ}$ tipo: Determinação do comportamento biológico de um tecido tumoral

Este é o principal objetivo de muitos estudos em biologia molecular, destacando-se aqueles referentes à área oncológica, e é descrito como análise da expressão gênica tecidual.

Através desta análise, podemos compreender as funções de cada proteína mediante a correlação entre sua expressão tecidual e diferentes parâmetros clínicos e anatomo-patológicos observados, como grau de diferenciação tumoral, potencial metastático, resposta à terapêutica, intensidade de processos inflamatórios, prognóstico etc.

Como o comportamento biológico de uma célula ou um tecido, seja ele normal ou patológico, será determinado pela presença e concentração das proteínas existentes em seu interior, os métodos anteriormente citados para determinar a seqüência gênica no DNA não se aplicam neste caso, pois todos os genes deverão estar presentes em todas as células somáticas de nosso corpo, independentemente de serem ou não ativados para a produção de sua respectiva proteína. Desta forma, o gene da insulina, por exemplo, se mostrará presente e íntegro em células como neurônios ou linfócitos, embora não ocorra sua ativação (expressão) visando à produção desta proteína nestas células.

Assim sendo, toda célula, seja ela um organismo independente como uma bactéria ou integrante de um grande organismo multicelular como um hepatócito ou célula tumoral, terá suas funções realizadas pela ação de milhares de proteínas distintas, formadas a partir de um número equivalente de RNAs mensageiros, os quais foram produzidos sobre os respectivos genes em seu DNA. Assim sendo, podemos estudar o comportamento biológico de cada célula através da determinação do estado funcional e integridade de uma proteína ou um conjunto delas. 
É importante destacar que, ao contrário dos estudos anteriores, em que o foco estava sobre o código genético do indivíduo e portanto presente em qualquer célula somática, neste caso necessitaremos fazer a análise biomolecular específica do tecido a ser estudado, seja ele um tumor, um processo inflamatório, ou mesmo um tecido normal cuja atividade celular fisiológica necessite ser esclarecida.

Para esta avaliação, dispomos de duas abordagens distintas, a saber:

\section{Pesquisa do RNAm de uma determina- da proteína}

Considerando a seqüência:

DNA $\rightarrow$ RNAm $\rightarrow$ Proteína,

podemos concluir que, ao contrário da sequiência gênica do DNA, a qual estará presente em todas as células somáticas, seu respectivo RNA mensageiro (RNAm) somente estará presente em um tecido no qual tenha havido a ativação deste gene específico visando a produção de sua respectiva proteína.

Para identificarmos a presença deste RNAm, necessitamos inicialmente extrair, por meios bioquímicos, todo o RNA do tecido a ser analisado. Em seguida teremos que, através de reações químicas que utilizem uma enzima denominada como transcriptase reversa, reverter a transcrição deste RNAm em DNA novamente (em segmentos denominados como cDNA ou DNA complementar), os quais poderão ser quantificados, segundo o método de PCR descrito acima. Caso possamos identificar a presença deste, então iremos demonstrar que sua respectiva proteína está sendo produzida naquele tecido, pois foi formado a partir de um RNAm já existente. Este método de análise de expressão gênica é denominado como RT-PCR $(\mathrm{RT}=$ reverse transcriptase) e apresenta a vantagem de permitir a avaliação das proteínas produzidas naquele tecido, possibilitando uma análise do perfil genômico tumoral.

Uma aplicação mais sofisticada deste procedimento é denominada como microseqüência (microarrays), para a qual são utilizados os chamados 'microchips', possibilitando a identificação simultânea de milhares de genes que estão sendo ativados (ou não) no DNA daquele tecido. Este método, embora venha sendo aplicado cada vez mais em laboratórios avançados de pesquisa, é ainda bas- tante complexo para sua utilização em bases clínicas.

\section{no tecido \\ 2. Pesquisa da proteína propriamente dita \\ Para correlacionar o comportamento biológico} de um tecido diretamente com as proteínas ali expressas dispomos de dois procedimentos mais freqüentemente utilizados. O primeiro deles é a imunohistoquímica, já revista recentemente nesta Seção, a qual nos permite a visualização in loco da proteína em questão em um corte do tecido após sua reação com um anticorpo específico, como demonstrado na Figura 4.

A imunohistoquímica apresenta grandes vantagens, como sua maior disponibilidade em laboratórios de anatomia patológica, baixo custo, a possibilidade de identificação do posicionamento da proteína no tecido (nuclear, citoplasmática, etc) ou a intensidade de sua presença através do grau de coloração. Por outro lado, apresenta-se pouco adequada à análise estatística devido ao forte componente subjetivo na quantificação dos resultados durante a observação das lâminas.

Outra forma de demonstrar a presença de uma determinada proteína a ser estudada em um determinado tecido é através da técnica conhecida como Western blotting. Este método consiste na extração bioquímica de um pool, contendo todas as proteínas presentes no tecido, sendo estas posteriormente separadas por um processo de eletroforese.
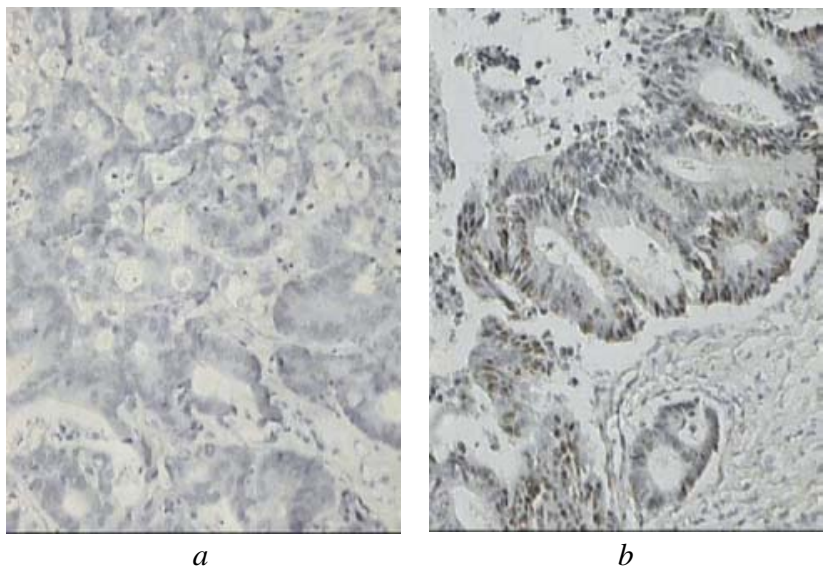

Figura 4 - Cortes histológicos de tecido tumoral (câncer colorretal) pela coloração convencional em (a) e imunohistoquímica em (b), na qual podemos observar a presença de proteína 553 (coloração acastanhada). 
Feito isto, a identificação de uma determinada proteína naquele tecido poderá ser feita através da adição de um anticorpo específico e sua demonstração através de corante, conforme demonstrada na Figura 5.

Assim sendo, o conhecimento destes tipos mais freqüentes de estruturas de pesquisa em biologia molecular representa, na verdade, a primeira etapa na elaboração de um projeto, pois baseia-se na disponibilidade de equipamentos e experiência de cada laboratório, devendo ser então o resultado de uma perfeita integração entre o pesquisador clínico e o grupo de profissionais que atuam neste, incluindo outros profissionais da área de saúde, como biologia, bioquímica e farmácia.

Uma vez definidos os recursos disponíveis e a estrutura do projeto, restará ao pesquisador enfrentar outra etapa bastante complexa, referente à definição dos elementos biomoleculares a serem estudados. Discutiremos esta delicada etapa em um próximo número desta seção.

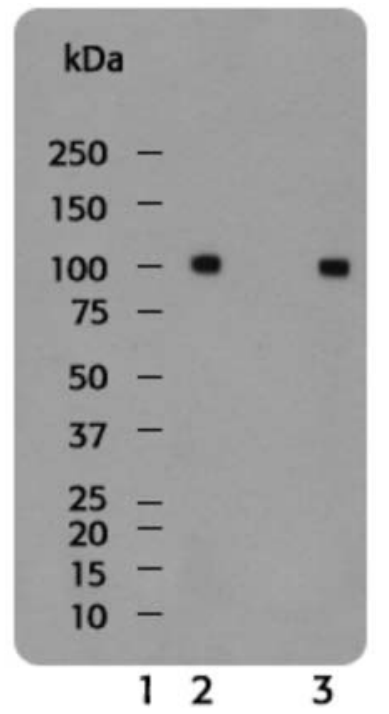

Figura 5 - Técnica de Western-Blotting. Observa-se na avaliação de duas amostras $(2$ e 3) a presença de uma banda de peso molecular correspondendo a $100 \mathrm{kDa}$, demonstrando a existência da proteína pesquisada no presente espécime. (Extraído de www.upstate.com)

\footnotetext{
ABSTRACT: Molecular biology studies are presently regarded as a major source for research in Medicine, and an increasing number of medical professionals are interested in improving their knowledge and scientific production in this subject. However, structuring the research project may become a difficult challenge due to the wide range of methods and techniques available in this area, most of them depending on existing technological facilities and personal skill. The aim of this study is to contribute for the task of setting up a research project by presenting a brief review of most used structure models in molecular biology studies as well as its related principles and methods.
}

Key words: Research; Molecular biology.

\section{REFERÊNCIAS}

1. Alberts e cols. Fundamentos da Biologia Celular, Artmed, 1999.

2. Lodish e cols. Biologia Celular e Molecular, Revinter, 2002.

3. Pinho M. Biologia Molecular do Câncer, Revinter, 2005.

4. Croner RS, Peters A, Brueckl WM, Matzel KE, Klein-Hitpass L, Brabletz T, Papadopoulos T, Hohenberger W, Reingruber B, Lausen B. Microarray versus conventional prediction of lymph node metastasis in colorectal carcinoma. Cancer. 2005 Jul 15;104(2):395-404.

5. Eschrich S, Yang I, Bloom G, Kwong KY, Boulware D, Cantor A, Coppola D, Kruhoffer M, Aaltonen L, Orntoft TF,
Quackenbush J, Yeatman TJ. Molecular staging for survival prediction of colorectal cancer patients. J Clin Oncol. 2005 May 20;23(15):3526-35.

6. Pinho M. Imunoistoquímica: o estudo da biologia molecular ao alcance de todos. Ver Bras Coloproctologia 2005;25:18891 .

Endereço para correspondência:

MAURO PINHO

Rua Palmares, 380

89.203-230 - Joinville (SC) 